\title{
PENERAPAN PRINSIP BLUE ECONOMY PADA MASYARAKAT PESISIR DI KABUPATEN BREBES, JAWA TENGAH
}

\author{
*Mira, Maulana Firdaus dan Elly Reswati \\ Balai Besar Penelitian Sosial Ekonomi Kelautan dan Perikanan \\ Gedung Balitbang KP I Lt. 4 \\ Jalan Pasir Putih Nomor 1 Ancol Timur, Jakarta Utara \\ Telp: (021) 64711583 Fax: 64700924 \\ *e-mail: miraclenia@yahoo.com \\ Diterima 20 Februari 2014- Disetujui 25 Mei 2014
}

\begin{abstract}
ABSTRAK
Konsep blue economy sudah menjadi perhatian dalam pembangunan sektor perikanan di Indonesia. Hal ini diindikasikan dengan dirumuskannya sebuah konsep pengembangan blue economy untuk kelautan dan perikanan Indonesia. Pada tahun 2013 Kementerian Kelautan dan Perikanan melalui Balai Besar Penelitian Sosial Ekonomi Kelautan dan Perikanan (BBSEKP) melakukan identifikasi penerapan prinsip blue economy pada lokasi sasaran pengembangan Klinik Iptek Mina Bisnis (KIMBIS) di wilayah pesisir Kabupaten Brebes, Jawa Tengah. Penelitian dilakukan dengan menggunakan data primer dan sekunder yang dianalisis dengan pendekatan deskriptif-kualitatif. Hasil penelitian menunjukkan bahwa terdapat tiga usaha perikanan dan kelautan yang telah menerapkan prinsip-prinsip blue economy di lokasi penelitrian, yaitu: usaha longyam, polikultur, dan usaha pengolahan kulit ikan menjadi kerupuk. Untuk lebih meningkatkan tingkat penerapan prinsip blue economy pada ketiga usaha tersebut, perlu dukungan pemerintah baik berupa sarana maupun prasarana yang lebih baik dengan disertai upaya pendampingan yang lebih intensif.
\end{abstract}

Kata kunci: prinsip, blue economy, masyarakat pesisir

Abstract : The Application of The Principles of Blue Economy on Coastal Society In Brebes District, Central Java Province. By Mira and Maulana Firdaus

The concept of blue economy has been concern in the development of fisheries sector in indonesia.lt is indicated by he formulated is a the development of a blue economy to maritime and fisheries of indonesia.In 2013 marine ministry and fishery through balai large research socioeconomic marine and fisheries to conduct identification the application of the principles of blue economy one of them at the coastal region district besides, central java.Besides district is one of the location of the target the development of science and technology clinic mina business which in the initiation by bbpsekp.This research aimed at analyzing do business maritime and fishery that develops in society pesisir ve been watching the principles of blue economy. The result showed that there are three business fishery and maritime that have implemented the principles of blue economy as at a venture longyam, polikultur, and business processing skin of fishes into cracker.

Keywords : principles, blue economy, coastal society

\section{PENDAHULUAN}

Pengurangan kemiskinan pada masyarakat di wilayah pesisir memerlukan perubahan paradigma pembangunan dari yang berorientasi terestrial ke yang berwawasan maritim (revolusi biru). Pengalihan sasaran pembangunan ke wilayah pesisir dan laut merupakan salah satu alternatif pembangunan yang selama ini hanya bertumpuh pada sektor pertaniaan dengan tingkat kejenuhan yang sudah semakin tinggi. $\mathrm{Hal}$ tersebut tetap untuk memadukan tiga kepentingan pembangunan, yaitu: mendorong pertumbuhan ekonomi, meningkatkan kesejahteraan masyarakat, serta menjaga kualitas sumberdaya dan lingkungan. Upaya memadukan ketiga kepentingan tersebut diantaranya dapat ditempuh melalui penerapan prinsip-prinsip yang terdapat dalam kon sep Blue Economy (Pauli, 2010).
Pada tahun 2010 telah diperkenalkan konsep Blue Economy oleh Gunter Pauli melalui bukunya berjudul The Blue Economy. Hal ini salah satu yang mendasari peralihan pembangunan dari terestrial ke maritim, juga karena pertimbangan potensi dari Indonesia, yang merupakan negara kepulauan terbesar di dunia, menerapkan ekonomi hijau saja tidak cukup perlu dibarengi dengan konsep ekonomi biru. Oleh karena itu, pemerintah terus mengusung prinsip ekonomi biru (blue economy) di dalam setiap perencanaan pembangunannya.

Konsep blue economy yang sudah dibuat tersebut perlu diuji pada tingkat lapang, terutama menyangkut penerapan prinsip - prinsipnya. Hal ini penting karena menyangkut pentingnya mensosialisasikan prinsip-prinsip blue economy ke 
masyarakat perikanan (nelayan, pembudidaya industri, pemasar, dan NGO). Selain itu, atas pertimbangan sudah banyak nilai-nilai kearifan lokal yang menerapkan prinsip blue economy, misalnya sasi atau panglima laot yang mempertimbangkan aspek pelestarian perikanan dan distribusi sumber daya yang berkelanjutan. Artinya, bagaimana menyelaraskan antara kearifan lokal tersebut dengan konsep-konsep blue economy untuk mewujudkan pembangunan kelautan dan perikanan yang lestari dan berkelanjutan.

Pada tahun 2013 Kementerian Kelautan dan Perikanan melalui Balai Besar Penelitian Sosial Ekonomi Kelautan dan Perikanan (BBSEKP) melakukan identifikasi penerapan prinsip-prinsip blue economy di lokasi sasaran pengembangan Klinik Iptek Mina Bisnis (KIMBIS) pada wilayah pesisir Kabupaten Brebes, Jawa Tengah yang di inisiasi oleh BBPSEKP. Salah satu peran dari KIMBIS di Kabupaten Brebes adalah mengintroduksikan teknologi hasil Balitbang KP yang diharapkan akan meningkatkan nilai tambah hasil produksi perikanan yang pada akhirnya menumbuhkan pekerjaan alternatif dan tambahan pendapatan bagi rumah tangga perikanan. Terkait dengan hal tersebut, penelitian ini merupakan bagian dari kegiatan pelaksanaan Klinik Iptek Mina Bisnis di Kabupaten Brebes dan bertujuan untuk menganalisis penerapan prinsip blue economy pada usaha kelautan dan perikanan yang berkembang di masyarakat pesisir.

\section{METODOLOGI}

\section{Waktu dan Lokasi Penelitian}

Penelitian ini dilakukan pada tahun 2013 di wilayah kerja Kimbis Kabupaten Brebes, Jawa Tengah, dengan mengambil beberapa lokasi contoh, yaitu: di Desa Grinting, Desa Kaliwlingi dan Desa Randu Sanga.

\section{Jenis, Sumber dan Cara Pengumpulan Data}

Data yang digunakan dalam penelitian ini dadalah data primer berupa Data itu berupa peluang, dan tantangan dalam penerapan prinsip-prinsip blue economy dalam usaha perikanan atau teknologi yang digunakan oleh mayarakat kelautan dan perikanan. Data diperoleh dari sumber hasil diskusi, wawancara, dan FGD dengan stakeholder perikanan kelautan. Data peluang, dan tantangan dalam penerapan prinsip-prinsip blue economy dalam usaha perikanan atau teknologi yang digunakan dalam penelitian ini, pada pkoknya berupa efek pengganda, minimize waste, inovatif dan adaptif dan inklusi sosial.

\section{Metode Pengambilan Data}

Untuk Identifikasi data potensi, teknologi yang menerapkan prinsip blue economy di Kabupaten Brebes dilakukan secara bertahap yaitu dimulai dari pengamatan langsung, mendiskusikannya dengan informan kunci dari pejabat dinas terkait, tokoh masyarakat setempat, wawancara dengan pelaku usaha budidaya, pengolah, dan nelayan. Selain itu sebelumnya dirumuskan dalam forum diskusi kelompok terfokus (FGD) yang dilakukan pada tahap awal pelaksanaan Kimbis, dimana saat itu dilakukan sosialisasi prinsip-prinsip blue economy kepada Dinas Kelautan Perikanan, pengurus Kimbis, Penyuluh, dan pelaku usaha. Obyek survey pelaku usaha perikanan dan kelautan yang ada de Grinting dan desa lainnya (Kaliwlingi dan Randu Sanga) di Brebes. Salah satu contoh identifikasi potensi penerapan blue economy di lapang adalah polikultur dan pengolahan kulit ikan menjadi kerupuk atau pengolahan produk lanjutan dari bandeng, rumput laut, dan bandeng.

\section{Metode Penentuan Responden}

Responden atau Informan yang digunakan dalam penelitian ini dipilih dengan menggunakan teknik purposive sampling terkait dengan pelaku usaha kelautan dan perikanan yang menerapkan prinsipprinsip blue economy di Desa Grinting, Kaliwlingi, dan Randu Sanga yaitu sebanyak 20 orang.

\section{Metode Analisis Data}

Penelitian ini berupa kualitatif deskriptif. Analisis data secara deskriptif dnegan tujuan untuk menyederhanakan data kedalam bentuk yang mudah dipahami (Singarimbun. 1989). Data yang dikumpulkan kemudian dituangkan dalam matrik potensi penerapan blue economy, solusi dan permasalahan penerapan dari blue economy. Diharapkan dengan mengidentifikasi unsur blue economy pada Kimbis bisa mempublikasikan konsep ke industri perikanan untuk menciptakan produk yang efesien. Selain itu hal yang tidak kalah penting adalah untuk melihat penerapan prinsip-prinsip blue economy pada tingkat masyarakat lokal dalam hal ini nelayan atau masyarakat pesisir. Hal ini disebabkan dibeberapa wilayah Indonesia, sudah ada prinsip blue economy yang sudah diterapkan, misalnya usaha mina padi, dan di Brebes misalnya usaha polikultur antara rumput laut, bandeng, dan udang.

\section{IDENTIFIKASI USAHA KELAUTAN DAN PERIKANAN YANG MENERAPKAN PRINSIP BLUE ECONOMY}

Konsep blue economy sendiri sudah menjadi perhatian dalam pembangunan sektor perikanan di Indonesia. Hal ini diindikasikan dengan dirumuskannya sebuah konsep pengembangan blue economy untuk kelautan dan perikanan Indonesia pada sebuah workshop di Bogor pada tanggal 23 April 2012 oleh Kementrian Kelautan dan Perikanan. Dimana konsep tersebut dibuat berdasarkan pertimbangan pro job, pro poor, pro growth dan pro environment. Konsep tersebut diselaraskan dengan kebijakan pembangunan kelautan perikanan yang sudah dibuat misalnya kebijakan revolusi biru, minapolitan, program industrialisasi perikanan, 
dan kebijakan kebijakan transaksi transfer produksi low carbon (Sunoto, 2013).

Sistem usaha kelautan dan perikanan yang menerapkan prinsip-prinsip blue economy di lokasi penelitian baru kentara pada kegiatan usaha perikanan budidaya dan pengolahan. Pada kegiatan budidaya usaha perikanan yang menerapkan prinsip blue ecpnomy adalah pada sistem usaha polikultur di tambak, baik itu antara udang dan rumput laut, atau antara bandeng dan rumput laut, atau untuk ketiga komoditas tersebut yaitu antara udang, bandeng, dan rumput laut. Pada usaha pengolahan ikan di lokasi penelitian yang sudah menerapkan prinsip-prinsip blue economy adalah usaha pengolahan kulit dan tulang ikan menjadi kerupuk.

\section{Tabel 1. Usaha Perikanan yang Menerapkan Prinsip-Prinsip Blue Economy pada Masyarakat Pesisir di Kabupaten Brebes, Jawa Tengah Tahun 2013.}

\begin{tabular}{lll}
\hline No & $\begin{array}{l}\text { Tipe usaha } \\
\text { Perikanan }\end{array}$ & \multicolumn{1}{c}{$\begin{array}{c}\text { Usaha yang Menerapkan } \\
\text { Prinsip Blue Economy }\end{array}$} \\
\hline 1 & $\begin{array}{l}\text { Perikanan } \\
\text { Budidaya }\end{array}$ & Longyam dan Polikultur \\
2 & $\begin{array}{l}\text { Perikanan } \\
\text { Pengolahan }\end{array}$ & $\begin{array}{l}\text { Pengolahan kulit menjadi } \\
\text { kerupuk }\end{array}$ \\
\hline
\end{tabular}

Sumber : Data Primer Diolah, 2013.

\section{Sistem Usaha Terpadu Antara Perikanan dan Peternakan (Longyam)}

Identifikasi penerapan prinsip blue economy di Brebes salah satunya ada di desa Kali Wlingi adalah sistem usaha terpadu antara perikanan dan pertenakan ayam dalam istilah yang banyak dikenal orang adalah longyam. Sistem usaha ini dimasukan ke prinsip blue economy yang meminimalkan limbah dan pengelolaan usaha yang efesien. Sistem usaha yang terpadu antara perikanan dan peternakan di desa Kali Wlingi belum banyak diusahakan, tapi sudah beberapa rumah tangga perikanan (RTP) yang mengelola usaha ini.

Usaha terpadu menurut Sulaiman (2007) pada hakekatnya merupakan sistem usaha yang mampu menjaga keseimbangan ekosistem, sehingga aliran nutrisi (unsur hara) dan energi terjadi secara seimbang. Apabila usaha dikembangkan secara sendiri-sendiri maka limbah dari usaha tersebut dalam hal ini usaha ternak ayam adalah kotoran dari ternak merupakan limbah yang dapat menimbulkan masalah dan penanganannya memerlukan biaya yang tinggi pada produksi usaha peternakan ayam.

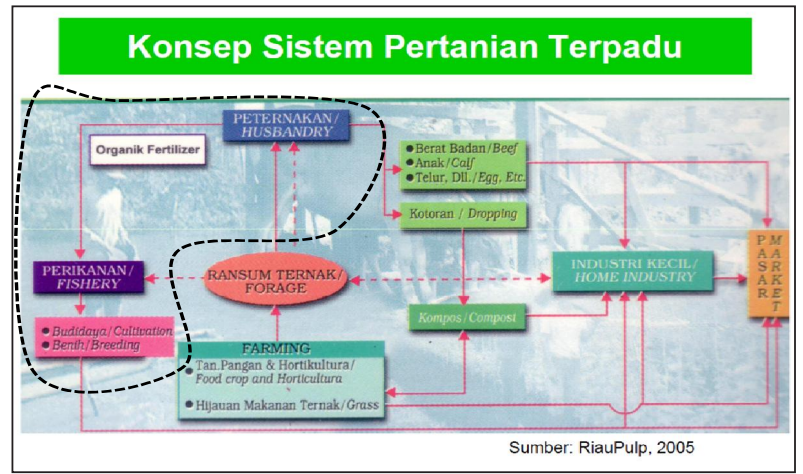

Gambar 1. Sistem Usaha Terpadu Antara Perikanan dan Pertanian.

Sistem usaha terpadu antara perikanan dan peternakan ayam yang ada di Desa kaliwlingi merupakan salah satu praktek usaha dimana "micro output" dari satu usaha menjadi input usaha lainnya. Multiplier effect-nya adalah akan meningkatkan kesuburan tanah dengan tindakan alami menyeimbangkan semua unsur hara organik yang pada akhirnya membuka jalan untuk pertanian organik ramah lingkungan dan berkelanjutan. Hal yang menyebabkan usaha longyam ini ramah lingkungan dan berkelanjutan adalah karena sistem usaha yang dijalankan menggunakan daur ulang

Tabel 2 . Prinsip-Prinsip Blue Economy Pada Usaha Longyam pada Masyarakat Pesisir di Kabupaten Brebes, Jawa Tengah Tahun 2013.

\begin{tabular}{ll}
\multicolumn{1}{c}{ Prinsip Blue Economy } & \multicolumn{1}{c}{ Penerapan Prinsip Blue Economy } \\
\hline Minimize waste & $\begin{array}{l}\text { Memanfaatkan kotoran ayam untuk pakan ikan, dimana satu usaha } \\
\text { longyam menghasilkan } 5 \text { karung kotoran/bulan }\end{array}$ \\
Multiplier effect & $\begin{array}{l}\text { Munculnya usaha lele yang tadinya hanya usaha pembesaran ayam, } \\
\text { dimana pendapatan pembudidaya lele Rp 500.000/bulan }\end{array}$ \\
Inklusi Sosial & Melibatkan 2-3 tenaga kerja/usaha longyam \\
Inovasi dan adaptif & Inovasi memanfaatkan limbah tapi tidak direkomendasikan karena tidak \\
Peluang & Sesuai dengan prinsip CBIB \\
Kendala & Kecil, karena tidak sesuai dengan CBIB \\
\hline
\end{tabular}

Sumber : Data Primer Diolah, 2013. 
menggunakan kotoran ayam dari usaha peternakan yang digunakan sebagai atraktan plankton yang dibutuhkan pada usaha perikanan, Dengan demikian, sistem usaha longyam ini mampu menciptakan suatu ekosistem yang ramah lingkungan, dimana sampah ternak diolah menjadi input usaha perikanan, sehingga limbah sampah dari usaha ternak ayam yang bau mampu diminimalkan dengan memanfaatkannya sebagai input pada usaha perikanan. Sistem usaha terpadu mampu menghasilkan produktivitas yang tinggi dan keberlanjutan produksi yang terjaga secara efektif dan efisien.

Kendala dalam penerapan sistem usaha terpadu antara peternakan ayam dan usaha perikanan di Desa Kali Wlingi adalah tidak dilakukannya system usaha ini secara massal pada suatu wilayah, tetapi hanya beberapa RTP (rumahtangga perikanan) saja. Padahal agar proses usaha terpadu berjalan secara efektif dan efesien, menurut Sulaiman (2007) sebaiknya usaha tersebut berada dalam suatu kawasan dan dilaksanakan secara terpadu. Hanya beberapa RTP yang melaksanan usaha ini, karena usaha polikultur usaha tambak lebih menguntungkan jika dibandingkan dengan usaha terpadu antara perikanan dan ayam ini.

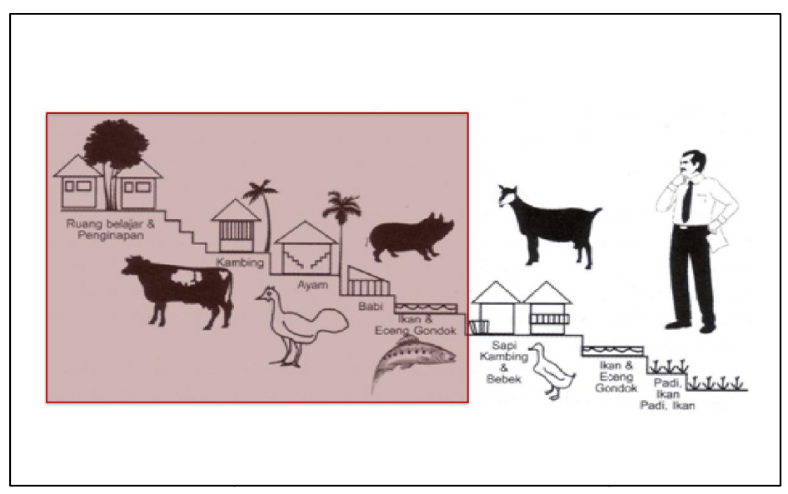

Gambar 2 . Tahapan Penerapan Prinsip Blue Economy Pada Usaha Longyam.

Sumber: RiauPulp (2005)

Kendala lain dari usaha terpadu longyam di Kali Wlingi adalah masih menggunakan teknik terpadu konvensional, dimana sistem usaha terpadu sudah banyak diterapkan oleh masyarakat pada masa lalu, namun sekarang sudah banyak ditinggalkan. Hal yang sama berlaku juga di Desa Kali Wlingi, dimana usaha terpadu longyam jumlah rumah tangga yang menggeluti usaha ini semakin sedikit. Padahal seharusnya usaha terpadu longyam yang ideal harus menggunakan sistem usaha dengan menggunakan teknologi EM (effective micro-organisme) dan menggunakan sistem usaha terpadu sekaligus manajemen limbah terpadu (IF-IWM) sehingga benar-benar menerapkan prinsip blue economy, yaitu pengelolaan usaha yang dapat mengurangi limbah dari usaha.

Menurut dari hasil wawancara yang dilakukan dengan pengusaha longyam manfaat dari sistem longyam ini adalah ada "asuransi" jika panen salah satu komoditas gagal, misalnya pada usaha longyam ini, jika usaha ternak ayam kurang menguntungkan maka bisa ditutupi dengan keuntungan yang diperoleh dari usaha ikan.

\section{b. Sistem Polikultur Usaha Pada Tambak (Rumput laut, bandeng, dan udang)}

Peluang penerapan Polikultur sebagai implementasi prinsip blue economy cukup besar di Brebes, namun yang menjadi kendala adalah penerapan teknologi ini adalah penambahan biaya operasional. Selain itu, petambak juga harus ada peningkatan pengetahuan bila ingin mengimplementasikan polikultur. Peningkatan pengetahuan tersebut menyangkut umur panen rumput laut, bandeng, dan udang. Hal ini disebabkan umur panen masing-masing komoditas berbeda-berbeda. Rumput laut dipanen pada umur 45 hari, udang dipanen setiap 2 bulan (karena hanya pembesaran), dan bandeng dipanen dalam waktu 6 bulan. Pengetahuan mengenai umur panen bisa diperoleh petani dari sesame petambak. Teknik polikultur yang banyak dilakukan di Brebes adalah antara bandeng dan rumput laut.

Prinsip minimize waste pada usaha polikultur bisa dilihat dari pemanfaatan kotoran ikan dan udang. Kotoran ikan tersebut sebagai sumber nutrien dari rumput laut. Sebaliknya rumput laut berfungsi sebagai sumber oksigen dan tempat berlindungnya bagi ikan dari predator. Petambak yang menerapkan polikultur pada usaha tambak menyadari unsur meminimalkan limbah dari usaha ini, dimana menurut mereka usaha polikultur ada pemanfaatan limbah dari kotoran ikan untuk rumput laut.

Prinsip inklusi sosial pada usaha polikultur bisa dilihat dari tidak terlalu banyaknya tambahan modal yang dibutuhkan dalam usaha ini. Tambahan modal tersebut berupa peningkatan biaya operasional untuk pembelian benih/bibit dari komoditas yang dipolikulturkan. Untuk kebutuhan lahan, tidak ada penambahan lahan untuk usaha polikultur ini, bahkan usaha polikultur memanfaatkan lahan secara optimal, serta tidak adanya perlakukan khusus yang mengharuskan petambak menggunakan teknologi yang canggih. Malah usaha polikultur hanya bisa dilakukan pada tambak yang menggunakan teknologi tradisional. Pada tambak yang menggunakan teknologi semi modern atau modern, malah tidak melakukan usaha polikultur.

Penerapan blue economy lainnya di Brebes adalah sistem polikultur antara udang, bandeng, dan rumput laut. Budidaya Gracillaria verrucosa, dan jenis rumput laut lainnya, dapat dilakukan secara monokultur dan polikultur bersama ikan (finfish) di tambak. Dengan menggunakan sistem budidaya polikultur dapat meningkatkan efisiensi penggunaan lahan tambak dan pendapatan pembudidaya secara berkesinambungan. Budidaya ini didasari atas prinsip keseimbangan alam. 
Tabel 3. Penerapan Prinsip Blue Economy Pada Usaha Tambak Polikultur pada Masyarakat Pesisir di Kabupaten Brebes, Jawa Tengah Tahun 2013.

\begin{tabular}{|c|c|}
\hline Prinsip Blue economy & Penerapan Prinsip Blue economy \\
\hline Minimize waste & $\begin{array}{l}\text { Sudah diterapkan di Brebes terutama di Randu Sanga dimana kotoran udang } \\
\text { dan bandeng untuk unsur hara rumput laut }\end{array}$ \\
\hline Multiplier effect & $\begin{array}{l}\text { Peningkatan pendapatan petambak menjadi Rp } 1.2 \text { juta per bulan dari yang } \\
\text { hanya Rp } 800 \text { ribu/bulan. Perapan polikultur akan meningkatkan biaya juga } \\
\text { meningkatkan penerimaan petambak. }\end{array}$ \\
\hline Inklusi Sosial & $\begin{array}{l}\text { Satu usaha polikultur melibatkan 3-5 tenaga kerja, apalagi usaha ini bisa } \\
\text { dilakukan semua masyarakat karena tidak membutuhkan modal yang cukup } \\
\text { besar }\end{array}$ \\
\hline Inovasi dan adaptif & $\begin{array}{l}\text { Inovasi dengan memanfaatkan kotoran ikan dan udang menjadi unsur hara bagi } \\
\text { pertumbuhan rumput laut }\end{array}$ \\
\hline Tantangan & Penambahan biaya operasional \\
\hline
\end{tabular}

Sumber:Data diolah, 2013

Rumput laut berfungsi sebagai penghasil oksigen dan tempat berlindung bagi ikan-ikan dan udang dari predator dan sebagai biological filter. Ikan dan udang membuang kotoran yang dapat dipakai sebagai nutrien oleh rumput laut, sedangkan rumput laut menyerap $\mathrm{CO}_{2}$ terlarut hasil pernapasan ikan dan udang.

Menurut Murachman et al., (2010), salah satu keuntungan dari sistem usaha polikultur yang mengintegrasikan rumput laut pada usaha budidaya ikan (bandeng atau udang) adalah berupa dampaknya yang positif pada peningkatan kualitas air tambak. Murachman menambahkan, Rumput laut dengan sifat biologisnya sebagai penghasil dan penyuplai oksigen terlarut dalam air melalui proses fotosintesis, sehingga rumput laut memiliki kemampuan untuk menyerap kelebihan nutrisi dan cemaran yang bersifat toksik di dalam perairan. Sedangkan ikan bandeng sebagai pemakan plankton merupakan pengendali terhadap kelebihan plankton dalam perairan. Kotoran udang, ikan bandeng dan bahan organik lainnya merupakan sumber hara yang dapat dimanfaatkan oleh rumput laut dan fitoplankton untuk pertumbuhan. Hubungan yang seperti ini dapat menyeimbangkan ekosistem perairan. Sehingga perlu diteliti tentang model pengelolaan budidaya polikultur udang windu, ikan bandeng dan rumput laut (Murachman, 2010).

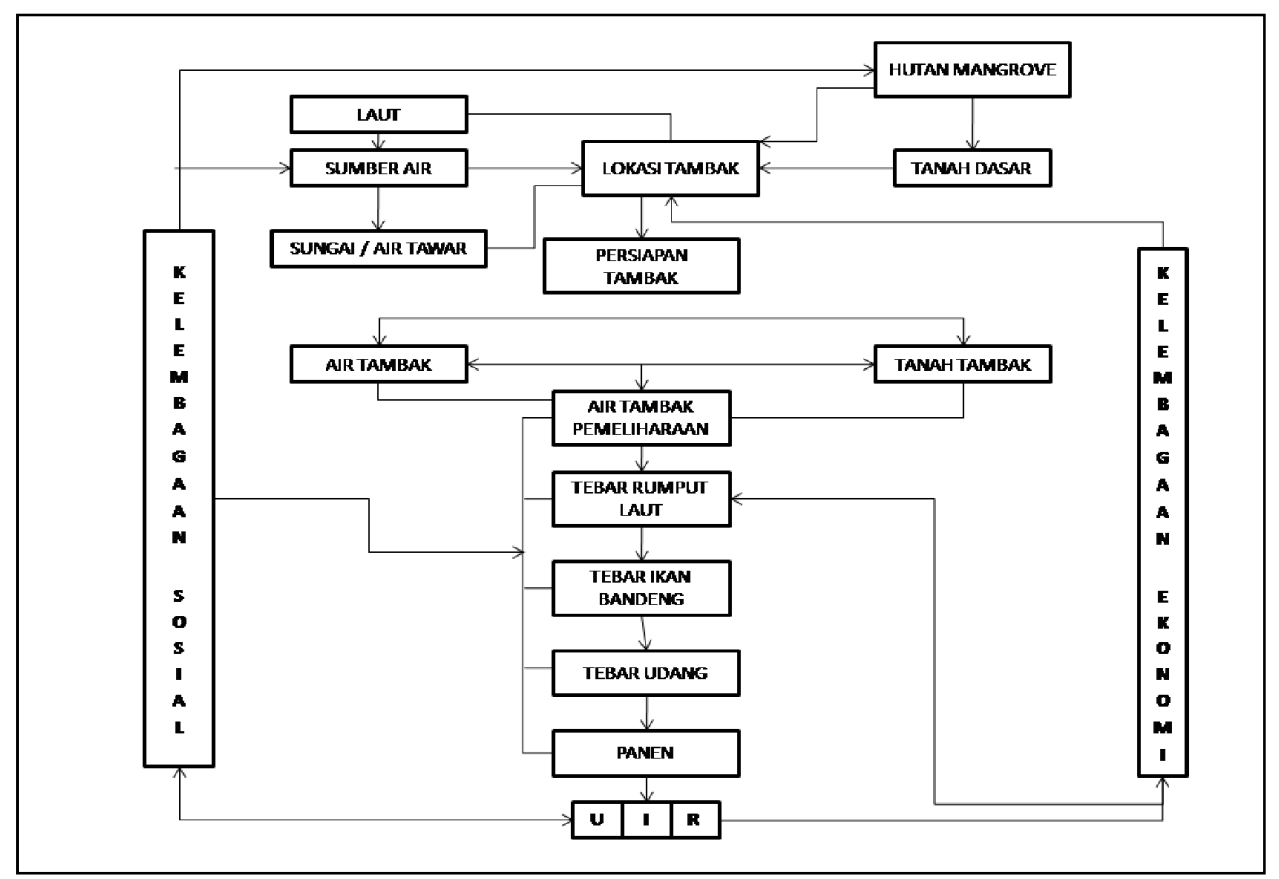

Gambar 3. Sistem Polikultur Bandeng, Udang dan Rumput Laut pada Masyarakat Pesisir di Kabupaten Brebes, Jawa Tengah Tahun 2013.

Sumber: Hasil pengamatan di lapang (2013) 


\section{PENERAPAN PRINSIP BLUE ECONOMY PADA USAHA PENGOLAHAN IKAN}

Prinsip blue economy yang diterapkan pada usaha yang mengolah kulit menjadi kerupuk ikan dan yang mengolah tulang ikan menjadi abon ikan. Prinsip blue economy yang diterapkan pada usaha ini adalah meminimalkan limbah, memiliki multiplier effect, melibatkan banyak tenaga kerja, dan memiliki inovasi dan adaptif. Usaha pengolahan kulit dan tulang ikan menjadi produk olahan baru telah dilakukan sejak awal tahun 2011. Kegiatan usaha ini berkembang seiring dengan adanya bantuan dari Direktorat Jenderal Pengolahan dan Pemasaran ikan dalam bentuk program bantuan PUMP.

Kendala dari usaha pengolahan kulit dan tulang ikan adalah bahan baku yang sulit didapatkan pada saat -saat tertentu. Saat ini, usaha tersebut sudah dilakukan oleh 3 usaha kecil, yang semua usaha tersebut mendapatkan bantuan PUMP P2HP. Peluang dari usaha pengolahan ini akan lebih besar lagi jika kendala bahan baku tersebut bisa diatasi. Respon pasar terhadap produk ini cukup bagus, seperti terbukti bahwa produk ini telah mampu menembus beberapa ritel di Bogor.

Prinsip minimize waste yang diterapkan pada usaha ini karena memanfaatkan tulang dan kulit ikan menjadi produk ikan olahan yang disukai oleh konsumen. Pengolahan kerupuk dan abon ikan dari kulit dan tulang ikan tentu saja meminimilkan limbah tulang ikan. Biasanya tulang dan kulit ikan dibuang, sekarang dimaanfaatkan oleh masyarakat pesisir. Prinsip multiplier effect diterapkan karena usaha pengolahan kerupuk dari kulit dan tulang ikan adalah meningkatkan pendapatan masyarakat dan dapat dijadikan sebagai mata pencarian alternatif. Selanjutnya prinsip inklusi sosial yang diterapkan pada usaha pengolahan karena dapat dilakukan semua masyarakat karena tidak membutuhkan modal yang besar. Inovasi yang dibuat adalah memanfaatkan limbah kulit dan tulang menjadi produk makanan. Usaha ini muncul dari ide banyaknya tulang dan kulit ikan yang dibuang, tapi tidak dimaanfaatkan.

Dari ketiga penerapan prinsip blue economy pada kegiatan usaha kelautan dan perikanan di Kabupaten Brebes, Jawa Tengah dalam dalam penerapan prinsip blue economy dapat dikelompokkan menjadi tiga tantangan. Pertama, tantangan internal dan eksternal diambil dari sisi nelayan, pelaku pemasaran atau industri perikanan (pengolah) yang menjadi the target groups dari penelitian ini. Adapun tantangan internal adalah pertama dari sisi nelayan (produsen) adalah masih banyaknya nelayan yang rendah pengetahuan, khususnya mengenai praktek penangkapan yang ramah lingkungan. Praktek yang tidak ramah lingkungan tersebut dipicu oleh tuntutan ekonomi dan lemahnya pengawasan dari peraturan perikanan, dan adanya penurunan hasil tangkapan yang disebabkan oleh over exploited.

Kedua, tantangan rendahnya kemampuan industri perikanan yang berkembang di Indonesia dalam menerapkan prinsip avoid waste, biodegradables, and Innovation. Hal ini disebabkan karena industri perikanan yang berkembang di Indonesia adalah industri rumah tangga yang mengalami keterbatasan dalam inovasi teknologi untuk menciptakan produk yang zero waste. Keterbatasan inovasi teknologi tersebut karena rendahnya pengetahuan dan lemahnya modal dalam usaha industri perikanan.

Ketiga, tantangan yang berasal dari penerapan prinsip efisiensi dalam pemasaran perikanan Indonesia. Selama ini yang menjadi masalah dari pemasaran perikanan adalah dominannya peran tengkulak ikan dalam penentuan harga. Hal ini akan mengakibatkan kurangnya distribusi tingkat keuntungan pada nelayan. Selain itu, sangat sulit menerapkan prinsip efesiensi dalam pemasaran perikanan karena panjangnya saluran pemasaran pada produk perikan, padahal produk perikanan merupakan produk yang cepat rusak dan busuk yang membutuhkan saluruan pemasaran yang pendek. Saluran pemasaran yang panjang ini tentu saja akan mempekecil efesiensi pemasaran.

Tabel 4. Prinsip-Prinsip Blue Economy Pada Usaha Pengolahan Ikan pada Masyarakat Pesisir di Kabupaten Brebes, Jawa Tengah Tahun 2013.

\begin{tabular}{ll}
\hline Prinsip Blue economy & \multicolumn{1}{c}{ Penerapan Prinsip Blue economy } \\
\hline Minimize waste & Di Kluwuk ada 5 usaha fillet ikan, dimana 1 minggu tulang dan kulit ikan itu tersebut \\
mencapai 1 ton & $\begin{array}{l}\text { Pengolahan usaha kerupuk kulit dan abon tulang mampu meningkatkan pendapatan } \\
\text { pengolaha mencapai Rp 600.000/bulan }\end{array}$ \\
Inklusi Sosial & $\begin{array}{l}\text { Tenaga kerja yang terlibat untuk usaha pengolahan kulit dan tulang ikan ini mencapai } \\
\text { I-2 orang }\end{array}$ \\
Inovasi dan adaptif & $\begin{array}{l}\text { Inovasi yang dibuat adalah memanfaatkan limbah kulit dan tulang menjadi produk } \\
\text { makanan. Usaha ini muncul dari ide banyaknya tulang dan kulit ikan yang dibuang, } \\
\text { tapi tidak dimaanfaatkan. }\end{array}$
\end{tabular}

Sumber: Data diolah, 2013 


\section{KESIMPULAN DAN REKOMENDASI KEBIJAKAN}

\section{Kesimpulan}

Terdapat tiga usaha perikanan dan kelautan pada masyarakat pesisir di Kabupaten Brebes, Jawa Tengah yang telah menerapkan prinsip-prinsip blue economy seperti pada usaha longyam, polikultur, dan usaha pengolahan kulit ikan menjadi kerupuk. Kendala dalam penerapan sistem usaha terpadu antara peternakan ayam dan usaha perikanan di desa Kaliwlingi adalah sistem usaha ini tidak dilakukan dengan massal pada suatu wilayah, hanya beberapa RTP saja. Padahal agar proses usaha terpadu berjalan secara efektif dan efesien, sebaiknya usaha tersebut berada dalam suatu kawasandan dilaksanakan secara terpadu.

\section{Rekomendasi Kebijakan}

Peluang penerapan Polikultur sebagai implementasi prinsip-prinsip blue economy cukup besar di Brebes, namun yang menjadi kendala adalah penerapan teknologi ini adalah penambahan biaya operasional akibat petambak mengimplementasikan dan tidak semua tambak bisa menerapkan polikultur. Kendala dari usaha pengolahan kulit dan tulang ikan adalah pada saat - saat tertentu bahan baku sulit didapatkan. Untuk lebih meningkatkan tingkat penerapan prinsip blue economy pada ketiga usaha tersebut, perlu dukungan pemerintah baik berupa sarana maupun prasarana yang lebih baik dengan disertai upaya pendampingan yang lebih inteensif.

\section{DAFTAR PUSTAKA}

Murachman. 2010. Model Polikultur Udang Windu (Penaeus monodon Fab), Ikan Bandeng (Chanos chanos Forskal) dan Rumput Laut (Gracillaria sp) Universitas Sumatera Utara Secara Tradisional. Jurnal Pembangunan dan Alam Lestari. Vol. 1 No. 1 Tahun 2010. No. ISSN. 2087-3522.

Pauli, Gunter. 2010. The Blue Economy. 10 Years, 100 Inovations, 100 Million Jobs. Paradigma Publications, Taos, New Mexico.

Singarimbun, M. dan S, Effendi. 1989. Metode Penelitian Survei. Penerbit LP3ES. Jakarta.

Sulaiman, M. 2007. Analisis Pendapatan Peternak Plasma Ayam Broiler Pada Sistem Bagi Hasil dan Sistem Kontrak. Skripsi. Program Studi Sosial Ekonomi Peternakan, Fakultas Peternakan, Institut Pertanian Bogor. Bogor.

Sunoto, 2013. Menuju Pembangunan Kelautan dan Perikanan Berkelanjutan dengan Konsep Blue Economy. Disampaikan pada workshop Blue Economy di Yogyakarta 7 Juni 2013. 